\title{
A Review of Theories and Practices of Multiliteracies in Classroom: Issues and Trends
}

\author{
Ang Leng Hong \\ Universiti Sains Malaysia, Malaysia \\ http://orcid.org/0000-0001-5688-7753 \\ Tan Kim Hua \\ Universiti Kebangsaan Malaysia, Malaysia \\ https://orcid.org/0000-0003-3787-5006
}

\begin{abstract}
This paper aims to review the concepts of literacy, multiliteracies, and multimodality in educational settings and their relevance in classroom practice. Literacy has emerged in recent years as an essential concept in the classroom teaching and learning process. With literacy views beyond the conventional print medium, it is important for teachers, educators, and learners to be given a new understanding of multiliteracies pedagogies. This paper also reflects on the development of multiliteracies paradigms. Specifically, it discusses the relevance and potentials of multimodal teaching and learning in dealing with the multiliteracies school learners bring into the classrooms including digital literacies and online literacies. This paper adopted a systematic literature review approach exploring issues and trends related to multiliteracies in the classroom context. The findings indicate that past studies often consider both the multimodality of meaning-making and meaningrecreating as well as different multiliteracies skills learners bring to the classroom. The review presented here addresses multiliteracies pedagogy in classroom teaching that benefits teachers, educators, and learners. Recommendations are made for future multiliteracies studies to strengthen the pedagogical practices in the emerging digital classroom.
\end{abstract}

Keywords: multiliteracies; classroom pedagogy; multimodal; meaningmaking; meaning-creating

\section{Introduction}

Over the past two decades, a revolutionary evolution in digital and interactive technology has taken place at an unprecedented pace - from emails, podcasts to iPhones and iPads. The avalanches of information generated by this development have radically turned the whole environment of human communication into a modern digital world of communication refined by technology (Whyte \& Schmid, 2019). The effect of this influx of new knowledge on our lives is real and too great 
to be ignored. Following an era of modern information technology, where new technologies pervade every aspect of communication and literacy, written language can no longer claim communicative sovereignty but is only as one of many ways of communicating (Zhang et al., 2019). The abundant multimodal ways to create meaning, where the written word is increasingly part of the auditory, visual, gestural, and spatial context of meaning patterns, make us understand the multiliteracy and multimodality values that are mobilised and circulated across the educational and communicational landscapes (Cope \& Kalantzis, 2015). In the age of digitisation, this pattern is much more prevalent where the dominance of monomodality has begun to reverse (Cloonan, 2015; Lim, 2021), making space for multimodality in representing meaning. As such, learning can no longer be regarded as a mechanism that merely depends on written words. The main objective of this paper is to discuss the concepts of literacy, multiliteracies, and multimodality in educational settings and their relevance in classroom practice. Also, it intends to address the pedagogical considerations and innovations adopted by teachers and learners in the current contexts.

\section{Literature Review}

The New London Group (NLG) (1996) called for a greater vision for literacy training to respond to the mass migration and proliferation of modern communications technology. The group argued that educational literacy pedagogy should embody the growing linguistic and cultural diversities of today's globalised world and reflect the new ways of textual interaction that have emerged due to new information and multimedia technologies. NLG has suggested the term multiliteracies to adequately capture the diversities of media, discourses, and languages. The revolutionary strategy of multiliteracies aims to reshape young people's social futures through diversity boundaries. Specifically, multiliteracies is a new fundamental way of literacy learning in a world characterised by social diversity and multimodal communication (Cope \& Kalantzis, 2015; Lim, 2021). The gist of the multiliteracies approach promotes the increasingly multimodal ways of making meaning and comprehending the fastchanging world, particularly the so-called digital world. Thus, the term multimodality has appeared in response to the changing social environment with regard to the increasingly popular digital world. The basic idea about multimodality is that the interpretation of meaning is rendered through configurations of image, motion, gaze, body position, sound, language, music, voice, etc. (Cloonan, 2015). From a multimodal point of view, the gesture, image, and other elements are referred to as modes, as organised sets of semiotic tools for meaning-making (Cope \& Kalantzis, 2015; Lim, 2021). The semiotic resources are the students' understandings and interpretations of sets of signs or symbols in order to make a text meaning. Specifically, there are five types of semiotic resources: linguistic, auditory, visual, spatial, and gestural (Cope \& Kalantzis, 2015; Neville, 2015).

The digital and online literacies often involve the representation of socially and culturally constructed self. This inherent desire to perform self among learners can be capitalised on by teachers to help them shape and design their social 
futures (Cope \& Kalantzis, 2015). The metalanguage tool kit available in multiliteracies provides these young learners with a range of functional grammars as representational resources to create different selves they wish to portray online socially and academically. The critical framing allows students to gain personal and analytical distance (Cope \& Kalantzis, 2015) to interpret the social context and purpose of meanings in multimodal texts.

Employing the multiliteracies framework may develop a more critical construction of self. Cope and Kalantzis (2015) proposed four elements in the multiliteracies pedagogy: situated practice, overt instruction, critical framing, and transformed practice. Adolescents come with some fairly basic digital and online literacies, such as constructing and sending emails, text messages, and online chats (Situated Practice). An introduction to explicit metalanguages can be done by the teachers, explaining to students about the proper choices of words, images, sound clips, font type/size/colour for online academic discussion and casual online chat (Overt Instruction). Therefore, students can select the proper linguistic and metalanguages for their presentation of self to other virtual community members in school (Critical Framing). At the final stage, students synchronise the available knowledge and tools and transmit the transformed meaning manifested in the constructed virtual self into cyberspace (Transformed Practice).

Previously, linguistic semiotic resources dominated literacy pedagogy when texts were either spoken or written. Nevertheless, as digital literacies rapidly impinge on our present working, public, and personal lives, all tect forms are increasingly multimodal. In educational settings, multimodal teaching and learning has gained more attention in the past two decades following the seminal publication of the NLG. Multimodality and multiliteracies initiatives are seen fostering classroom teaching practices that address student expectations for existing teaching and learning trends that contribute to their social interaction. Seemingly, the aim of multiliteracies pedagogic is to address the multimodal texts and various literary practices in which young people are engaged. In short, the concept of multiliteracies attempts to address both the definition of literacy and the implications of the practices needed for the many and diverse contexts of 21st-century life.

Broadly, multiliteracies involve various forms of learning. Multiliteracies pedagogy extends the teaching and learning process by incorporating what is new in the existing environment. Thus, it is essential for educators to have multimodal learning experiences for students. Multimodal learning facilitates the use of modern media and modes developed to take advantage of different multimedia and device technology (Abrams, 2015; Nabhan, 2019; Serafini \& Gee, 2017; Butler, 2019). These media and technology may be applied alongside conventional lectures and classes, tutorials, and textbooks to include alternative learning opportunities with different learning goals. Multimodal classroom learning allows educators to include various approaches for diverse learners in different learning environments (Whyte \& Schmid, 2019). The multimodal literacies principle promotes the use of independent learning materials to make 
learning flexible to cater to the needs and objectives of individual learner. Various resources such as computer-based and printed teaching and learning materials should be available to enable teachers as well as students to teach and learn efficiently (Nadzrah, 2007; Tan \& Guo, 2010; Kaur, Malini \& Sidhu, 2011; Christiansen, Li \& Bailey, 2017; Fariza \& Isma, 2018; Nabhan, 2019; Santori \& Smith, 2019). In short, multimodal teaching and learning strives to incorporate information and multimedia technologies to provide an interactive learning environment and enable students to comprehend different forms of texts. Therefore, they can negotiate the way they make meaning concerning their identities and beliefs about the present and future world.

Young people are facing an era in which literacy practices are profoundly altered. Their lives are being permeated by electronic and emerging technology. With access to computers and other digital devices, online communication has played an important role alongside conventional written and verbal communication in the younger generations' learning and socialising repertoire. They make a significant contribution to the prolific development of online technologies, especially social networking websites like Facebook and Twitter. Online interaction has become part of their regular communication repertoire with the world. This transition is both drastic and real in how young people read and write with words and pictures or images nowadays (Serafini \& Gee, 2017; Zhang et al., 2019). These online literacies motivate young people, such as school learners, to create and share content with others. Their mastery of these literacies is evident in the prolific production of digital texts through multiple modes of representation, including print, visual, and audio.

Digital technologies enable the construction of self by adolescents using words, images (photos, Avatar, emoticons), sounds (music or sound clips), and other modes of expression. The tendency of this literacy to be manifested in the adolescents' classroom literacy practices warrants the teachers' considerations and attention. The strong identification of young people with the new media, genres, and literacies generated are shaping their future, regardless of the possible resistance from the current older generation of print-oriented educators. This illuminates a pressing need to address and develop the literacies of adolescents to prepare them for the new dimensions of learning and communication in the online and digital world.

Besides, younger learners are recreating, modifying, and sharing the multimodal content by using new digital tools available online and offline. Thus, they define and make meaning from the multiple forms of texts to speak up their social identities and beliefs about the world. The multiple editable forms of text available online often provide various text entry points and pathways for young people, allowing them to remake texts and recreate meaning (Zhang et al., 2019). For instance, with various online semiotic resources and information seeking skills, creative and innovative adolescents can perform multimodal configurations, compositions, and combinations of music, voices, photographs, video clips, and written texts to produce a new form of online resources, such as the digital novel, digital comic book or any other genre. Besides, modern interactive technologies 
used to work with diverse forms of communication are changing how young people construct meaningful texts for themselves and those in their fields of affinity. For example, young learners with internet access are using various editing tools and other different design components (various semiotic resources) to produce digital games in a range of complexities (Butler, 2015, 2019).

In addition, videogames or computer games, a predilection among young learners are seen as the ideal vehicle to reach them, to see what and how they perceive the world. Game playing is becoming a new literate practice among young adolescents. Young people tend to spend time playing complicated games outside of classes. It is worth pointing out that from the educational perspective, the desire to use motivational power to inspire young learners to learn is the key driver of interest in digital learning games (Williams, 2017; Butler, 2019). Besides inspiring motivation, games are often considered highly useful to learn functional skills, increase perceptions, encourage and develop skills in problem-solving, strategic evaluation, media, and resources (Boyle et al., 2016; Butler, 2019; Tan \& Tan, 2020). Of all the games available, simulators are seen as the game mode that carries enormous educational potential.

One cannot deny that the multimodal literacies brought into the classrooms by adolescents are mostly digital and online literacies, with some fundamental print literacies. The mode of communication has vastly changed. The days of penciland-paper are fast being replaced by keyboard and touch screen. New technologies have provided a place to create new modes of communication, new ways to perceive, talk, and think about the world. Besides that, young people have also turned the sequential reading of the written word into non-linear and discontinuous digital text browsers (Mills, 2015). The familiarity with instantaneous access to and dissemination of digital texts in the cyberspace and digital world also shapes their literacy practices which are naturally brought into the classroom environment. All these bear a significant impact on the students' literacy expectations and the teachers' pedagogical innovations. The adolescents' multiliteracies outlined above could be acquired or learned through regular online practices and interactions. These interactions play a significant role in shaping the mindset of young people and, to a more considerable extent, influence their interaction with and production of multiple forms of texts, including pace and mode; and their identity construction and representation.

\section{Methodology}

In order to obtain an overview of the implementation of multiliteracies in the classroom, we undertook a systematic literature review in this research. Systematic review contributes to the body of knowledge and provides a solid basis for the advancement of knowledge in the field. It addresses questions that are difficult to address using quantitative methods or isolated qualitative research results (Finfgeld-Connett, 2014; Hainey et al., 2016). In addition to the systematic literature review, this paper adopted the principle of qualitative content analysis that is more flexible compared to the purely qualitative analysis method. The results were reported in the form of descriptive analyses. In this paper, the current 
trends and critical aspects in multiliteracies classrooms were reported and discussed.

The data in this research included previous studies concentrating on multiliteracies and multimodal learning in the classroom. The data were retrieved using Academic Search Complete and ERIC search engines as they are important education research databases. The string used included multiliterac* OR multimodal literac* OR multimodal learning. Multimodal literacy was recognised as a keyword as it is often used with multiliteracies synonymously. The search for articles targeted publications from 2015 to 2020 and yielded 105 articles. These articles were carefully read and reviewed to understand the current trends and critical aspects in multiliteracies classroom.

\section{Results}

The review shows that the digital explosion and the penetration of multimedia into the realm of school and education compel changes- changing literacies, changing mindsets, and changing pedagogies. Every change comes with initial resistance and challenges. This is more apparent when it comes to incorporating technology into the long-established tradition of education, especially when the proliferation of technologies dramatically outpaces the development in education (Hainey et al., 2016; Fariza \& Isma, 2018; Warner \& Depuy, 2018).

The implementation of the multiliteracies approach has not always been without a glitch. While some teachers enthusiastically move towards digitising teaching and learning, some are still nostalgic about the traditional print-based literacy. Researchers (e.g., Pishol \& Kaur, 2015; Chandler, 2017; Santori \& Smith, 2018; Zhang et al., 2019; Liang \& Lim, 2020) commented that this is the most challenging time for literacy pedagogy where teachers struggle against the transitional contradictions between the advance of modern digital literacy and the retrograde influence of traditional literacy. The perpetuation of the singular and monomodal notion of literacy by teachers will constantly be at odds with the multimodal literacies embraced by adolescents today. Accustomed to the multiple forms and modes of communication literacy practices on the screen, they can no longer be motivated solely by reading and writing on the page. This will have serious implications for literacy education in the classroom.

Also, challenges remain in incorporating multiliteracies practice into classroom teaching as the theoretical concept of multiliteracies is complex, and there seems to have a fuzzy area with regard to it being a pedagogical approach or a set of communication abilities (Palso \& Ruokano, 2015; Alagu \& Thanuskodi, 2019; Zhang et al., 2019). It, therefore, challenges the educators, especially teachers, in understanding the employment of the multiliteracies approach in classroom teaching.

The legitimisation of young people's digital and online literacies in mainstream education is not as easy as thought. While the potentials and capacity of adolescents' online literacies are honoured in the social space, their relevance for classroom practice is yet to be affirmed. Scholars observe students' expertise in 
creating online content and constructing social identities, while positively regarded by teachers, only receives "scant attention" in daily classroom practices (Mirra et al., 2018). This shows that some teachers need to change their pedagogical approaches to consider the advancement in technologies that fascinate the adolescents (Yunus, 2018; Mohd et al., 2020).

Confronted by the changing literacy needs in the multimedia environment, the changing lifeworlds of the learners, and the changing dimensions of school literacies when technologies are becoming part of classroom teaching and learning (Scherer, Siddiq \& Tondeur, 2019), teachers are facing greater challenges than never before in selecting and designing a pedagogy that can engage students in meaningful literacy practices in the sphere of technological learning. Researchers have urged teachers to adopt gamified learning that could interest both the teachers and learners. For instance, Mohd et al. (2020) suggested that language teachers incorporate gamified learning to help learners achieve better learning experiences. The concept of gamification was introduced by Pelling (2011) which was followed by many interactive applications such as Kahoot!, Quizzes, Plickers, Quizlet, and Socrative have been beneficial for school learners as learning through a fun environment enhances the retention of the lessons taught in the classroom. Researchers (Bullard \& Anderson, 2014; Poondej \& Lerdpornkulrat, 2016; Wichadee \& Pattanapichet, 2018; Mullins \& Sabherwal, 2018; Saienko \& Shevchenko, 2020) agreed that online language games are effective in improving learners' language skills. In this regard, Kahoot!, for instance, has the potential to elevate the enthusiasm of learners to learn the language in the classroom. Undoubtedly, game-based learning is emerging as a new multimodal resource that can facilitate teachers in motivating their students to learn actively. Nowadays, this game-based learning also recognises the gamebased literacy skills possessed by most adolescents.

\section{Discussion}

The review presented demonstrates the reality that trends and changes in the development of multiliteracies pedagogy proposed by New London Group (2000) are a continuum that integrates with the latest technologies available to both the educators and learners. However, beyond integrating with the technologies and multimodality, multiliteracies pedagogy needs to encompass various range of learners' social, linguistic, cultural, racial, and gendered identities in the classroom (Farashaiyan \& Tan, 2012; Boyd \& Brock, 2014; Zhang et al. 2019). To achieve this, teachers are required to engage with the literate practices that young people bring with them to classrooms (Philip et al., 2019). This involves understanding and appreciating young learners as meaning creators, the texts they create as meaning designs, and the process of making meanings with which young people are connected (Mirra et al., 2018; Zhang et al., 2019). These will offer insights into the kinds of resources young learners are able to use. Thus, teachers need to consider how to design pedagogic activities that can engage adolescents in higher levels of thinking about the nature of multimodal texts. To achieve this pedagogic goal, teachers will have to become more insightful about multimodal learning by looking at literacy in a new light. The idea of engaging in isolated text no longer applies to today's learners as they are exposed to more fluid forms of 
information and knowledge transfer (Lim \& Tan, 2018; Mirra et al., 2018; Liang \& $\mathrm{Lim}, 2020)$. Thus, teachers must realise that they need to engage with multimodal literacies as young adolescents do. In other words, teachers will have to improve their multimodal literacies concerning digital literacy knowledge before educating students about the subject matter.

To cope with the fast-changing trends in implementing multiliteracies pedagogy in the classroom, Mirra et al. (2018) proposed that educators and learners accept the critical multiliteracies theory that incorporates four ways of digital interaction. This includes critical digital consumption, critical digital production, critical distribution, and critical digital invention. Mirra et al. (2018) argued that the classroom pedagogy needs a radical revamping that requires an understanding of the notion of criticality by both teachers and learners. Specifically, the criticality in media literacies is the extension of the long-existing multiliteracies pedagogy proposed by the New London Group (2000). The critical digital consumption element suggested that learners do not only enjoy the multimodal learning resources available, but they also need to learn and produce digital multimedia contents to be globally competitive. To achieve this, learners need to understand, use, and deconstruct the tropes of the existing multimodal resources presented to them. This is achievable if both teachers and learners are exposed to the existing critical traditions and theories in the relevant education field. The exposure is essential to allow them to analyse the multimodal content critically.

Another critical multiliteracies pedagogy involves the practice of critical digital production (Mirra et al., 2018). To do so, learners require access to new technologies and resources to create multimedia materials, including textual, visual, and audio content such as short videos. Such trend is emerging as adolescents are using mobile applications such as Tik Tok to make short videos that can be shared online with other netizens (Lim, 2021). As such, teachers who advocate print literacy need to change their existing monomodal classroom practice by addressing the new and critical multiliteracies skills mastered by their students in order to achieve better learning outcomes (Unsworth \& Mills, 2020). Besides, teachers who actively move towards digitising teaching and learning need to motivate and encourage their students to think critically and learn actively in the classroom by learning to produce multimedia content relevant to the learning contents with their teacher's guidance.

The critical distribution sees the need for the learners to use, produce and share the appropriate multimedia content across different platforms such as Facebook, blogs, Tik Tok, and other social media sites (Mirra et al., 2018; Santori \& Smith, 2018). The fourth element in the critical theory of multiliteracies is the ability to invent new digital content, for instance, creating new software or mobile applications (Mirra et al., 2018). This is relatively challenging for many teachers and learners as it requires knowledge in computer programming. Therefore, the school should introduce programming lessons to learners in preparing them to be literate in this regard. The skill to invent new digital applications is critical to ensuring that new ideas are created to solve the most pressing challenge in today's context: the competition faced by learners in both local and global contexts. 
While the systematic review conducted attempted to provide substantial recapitulation of current issues and trends in multiliteracies classroom teaching and learning, some limitations need to be highlighted. First, it is possible that the specific search terms in the title of the publications did not fully cover all possible contributing research studies, since there are several peer-reviewed publications in which the title does not include these keywords, but they still appear in the text. Nevertheless, due to the tremendous work by researchers worldwide in the field of multiliteracies research, the analysis could not be comprehensive but could only cover representative academic literature. Second, this review focused on qualitative descriptive analysis with no particular attention given to the quantitative presentation of the related review. It is believed that future research may add a quantitative description to expand the line of review studies in the field of multiliteracies research.

\section{Conclusion}

To sum up, the review indicates that past studies often consider both the multimodality of meaning-making and meaning-recreating and the different multiliteracies skills learners bring to the classroom. This is in line with what the New London Group (2000) proposed, that educators and learners need to use the multimodal learning resources in classroom teaching and learning to address the multiliteracies skills possessed by learners. Research on classroom multiliteracies has received considerable attention, and it continues to be expanded in conjunction with the transformation in the $21^{\text {st }}$ century. The critical theory of multiliteracies proposed by Mirra et al. (2018) indicates the directions that future learners should move towards to communicate and compete with one another locally and globally.

Besides, the review of the related literature indicates that teachers ought to negotiate multiliteracies across a wide variety of multimodal pedagogical experiences in the classroom settings as these elements promote positive learning outcomes. Recognising the effect of multimedia technology on young learners' everyday lives, there has been a growing interest in how multimodal digital texts can be used in the educational context. As educators, we need to acknowledge the proliferation of multimodal ways of teaching and learning in pedagogic contexts in this $21^{\text {st }}$ century. Thus, teachers and policymakers have to make significant strides in integrating multimodal digital technologies into the curriculum, and the most important endeavour is to effectively implement the planned curriculum in all schools. Besides, teachers must think creatively in fulfilling students' learning needs by addressing the multimodal literacies students are engaged with and consequently aligning their pedagogies with the virtual world and other contexts. This will enable learners to develop their abilities to make meaning with multiple forms of texts surrounding them, thus helping them construct the values, identities, and beliefs about the world. 


\section{Acknowledgements}

This research was supported by the Ministry of Higher Education Malaysia grant FRGS/1/2018/SS09/UKM/02/1

This research was also funded by the School of Humanities, Universiti Sains Malaysia.

\section{References}

Abrams, S. S. (2015). Digital resources, Reflexive pedagogy, and empowered learning. In B. Cope \& M. Kalantzis (Eds.), A Pedagogy of multiliteracies: Learning by design (pp. 37-48). New York: Palgrave Macmillan.

Alagu, A., \& Thanuskodi, S. (2019). Bibliometric Analysis of Digital Literacy Research Output: A Global Perspective. Library Philosophy and Practice (e-journal), 2127.

Boyd, F. B., \& Brock, C. H. (2014). Social diversity within multiliteracies: Complexity in teaching and learning. New York: Taylor and Francis.

Boyle, E., Hainey, T., Connolly, T. M., Gray, G., Earp, J., Ott, M., Lim, T., Ninaus, M., Ribeiro, C., \& Pereira, J. (2016). An update to the systematic literature review of empirical evidence of the impacts and outcome of computer games and serious games. Computers $\&$ Education, 94, 178-192. https:// doi.org/10.1016/j.compedu.2015.11.003

Bullard, S. B., \& Anderson, N. (2014). "I'll Take Commas for \$200: An Instructional Intervention Using Games to Help Students Master Grammar Skills." Journalism $\mathcal{E}$ Mass Communication Educator, 69(1), 5-16. https:// doi.org/10.1177/1077695813518778

Butler, Y. G. (2015). English language education among young learners in East Asia: A review of current research (2004-2014). Language Teaching, 48(3), 303-342. https://doi.org/10.1017/s0261444815000105

Butler, Y. G. (2019). Gaming and young learners. In S. Garton \& F. Copland (Eds.). The Routledge Handbook of Teaching English to Young Learners (pp. 305-319). London: Routledge.

Chandler, P. D. (2017). To what extent are teachers well prepared to teach multimodal authoring? Cogent Education, 4(1), 1-19. https://doi.org/10.1080/2331186x.2016.1266820

Christiansen, M. S., Li, S., \& Bailey, M. R. (2017). The Role of Texting and Digital Multiliteracies in the EFL Classroom. MEXTESOL Journal, 41(3), 1-14.

Cloonan, A. (2015). Integrating by design: Multimodality, 21st century skills and subject area knowledge. In B. Cope \& M. Kalantzis (Eds.), A Pedagogy of multiliteracies: Learning by design (pp. 97-114). New York: Palgrave Macmillan.

Cope, B., \& Kalantzis, M. (2015). The things you do to know: An introduction to the pedagogy. In B. Cope \& M. Kalantzis (Eds.), A Pedagogy of multiliteracies: Learning by design (pp. 1-36). New York: Palgrave Macmillan.

Farashaiyan, A., \& Tan, K. H. (2012). A Cross-Cultural Comparative Study of Gratitude Strategies between Iranian and Malaysian Postgraduate Students. Asian Social Science, 8(7), 139-148. http:// doi.org/10.5539/ass.v8n7p139

Fariza, P. B., \& Isma, R. I. (2018). Multiliteracies Project Approach: Dated or a Worthy Learning Tool? GEMA Online Journal of Language Studies, 18(2), 312-334. http://doi.org/10.17576/gema-2018-1802-20

Finfgeld-Connett, D. (2014). Use of content analysis to conduct knowledge-building and theory-generating qualitative systematic reviews. Qualitative Research, 14, 341-352. http://doi.org/10.1177/1468794113481790 
Hainey, T., Connolly, T. M., Boyle, E. A., Wilson, A., \& Razak, A. (2016). A systematic literature review of games-based learning empirical evidence in primary education. Computers $\mathcal{E}$ Education, 102, 202-223. https://doi.org/10.1016/j.compedu.2016.09.001

Kaur, K., Malini, G., \& Sidhu, G. K. (2011). Designing Learning Elements Using the Multiliteracies Approach in an ESL Writing Classroom. 3L: The Southeast Asian Journal of English Language Studies, 18(3), 119 - 134. Retrieved from http:/ / ejournals.ukm.my/31/article/view/1116/1008

Liang, W. L. J., \& Lim, F. V. (2020). A pedagogical framework for digital multimodal composing in the English Language classroom. Innovation in Language Learning and Teaching, 1-15. https:/ / doi.org/10.1080/17501229.2020.1800709

Lim, F. V. (2021). Designing Learning with Embodied Teaching: Perspectives from Multimodality. London, New York: Routledge.

Lim, F. V., \& Tan, K. Y. S. (2018). Developing multimodal literacy through teaching the critical viewing of films in Singapore. Journal of Adolescent $\mathcal{E}$ Adult Literacy, 62(3), 291-300. https://doi.org/10.1002/jaal.882

Mills, K. A. (2015). Doing digital composition on the social web: Knowledge processes in literacy learning. In B. Cope \& M. Kalantzis (Eds.), A Pedagogy of multiliteracies: Learning by design (pp. 172-185). New York: Palgrave Macmillan.

Mirra, N., Morrell, E., \& Filipiak, D. (2018). From Digital Consumption to Digital Invention: Toward a New Critical Theory and Practice of Multiliteracies, Theory into Practice, 57(1), 12-19. https://doi.org/10.1080/00405841.2017.1390336

Mohd, I. I., Nur, E. M. S. \& Tan, K. H. (2020). Game-Based Learning Platform and its Effects on Present Tense Mastery: Evidence from an ESL Classroom. International Journal of Learning, Teaching and Educational Research, 19(5), 13-26. https://doi.org/10.26803/ijlter.19.5.2

Mullins, J. K., \& Sabherwal, R. (2018). Beyond Enjoyment: A Cognitive-Emotional Perspective of Gamification. In the Proceedings of the 51st Hawaii International Conference on System Science. Waikoloa Village, Hawaii: USA.

Nabhan, S. (2019). Bringing multiliteracies into process writing approach in ELT classroom: Implementation and reflection. Journal of English Education, Literature, and Culture, 4(2), 156-170. http://dx.doi.org/10.30659/e.4.2.156-170

Nadzrah, A. B. (2007). English language activities in computer-based learning environment: A case study in ESL Malaysian classroom. GEMA Journal of Language Studies, 7(1), 33-49. Retrieved from http:/ / ejournals.ukm.my/gema/article/view/186/159

New London Group. (1996). A pedagogy of multiliteracies: Designing social futures. Harvard Educational Review, 66(1), 60-92.

New London Group. (2000). A pedagogy of multiliteracies. In B. Cope, \& M. Kalantzis (Eds.), Multiliteracies: Literacy Learning and the Design of Social Futures (pp. 9-38). London: Routledge.

Pelling, N. (2011). The (short) prehistory of "gamification"... Funding Startups (E other impossibilities). $\quad$ Retrieved from https://nanodome.wordpress.com/2011/08/09/the-short-prehistory-ofgamification/

Philip, B., Tan, K. H., \& Jandar, W. (2019). Exploring Teacher Cognition in Malaysian ESL Classrooms. 3L: Language, Linguistics, Literature ${ }^{\circledR}, \quad 25(4), \quad 156-178$. http://doi.org/10.17576/3L-2019-2504-10

Poondej, C., \& Lerdpornkulrat, T. (2016). The development of gamified learning activities to increase student engagement in learning. Australian Educational Computing, 
31(2),

$1-16$.

Retrieved

from

http://journal.acce.edu.au/index.php/AEC/article/view/110

Santori, D., \& Smoth, C. A. (2018). Teaching and learning with iPads to support dialogic construction of multiliteracies, Middle School Journal, 49(1), 24-31. https:// doi.org/10.1080/00940771.2018.1398944

Saienko, N., \& Shevchenko, M. (2020). Authentic Videos in Teaching English to Engineering Students at Universities. International Journal of Learning, Teaching and Educational Research, 19(8), 350-370. https://doi.org/10.26803/ijlter.19.8.19

Scherer, R., Siddiq, F., \& Tondeur, J. (2019). The technology acceptance model (TAM): A meta-analytic structural equation modeling approach to explaining teachers' adoption of digital technology in education. Computers \& Education, 128, 13-35. https://doi.org/10.1016/j.compedu.2018.09.009

Serafini, F., \& Gee, E. (2017). Introduction. In F. Serafini \& E. Gee (Eds.). Remixing multiliteracies: Theory and practice from new London to new times (pp. 1-18). New York, NY: Teachers College Press.

Tan, L., \& Guo, L. (2010). From Print to Critical Multimedia Literacy: One Tecaher's Foray into New Literacies Practices. Journal of Adolescent $\mathcal{E}$ adult Literacy, 53(4), 315-324. https://doi.org/10.1598/JAAL.53.4.5

Tan, P. Q., \& Tan, K. H. (2020). In-game instructions: The extent of their usefulness in enhancing the vocabulary acquisition of ESL learners. International Journal of Emerging Technologies in Learning (iJET), 15(4), 73-89. https:// doi.org/10.3991/ijet.v15i04.11647

Unsworth, L., \& Mills, K. A. (2020). English language teaching of attitude and emotion in digital multimodal composition. Journal of Second Language Writing, 47, 1-17.

Warner, C., \& Dupuy, B. (2018). Moving toward multiliteracies in foreign language teaching: Past and present perspectives ... and beyond. Foreign Language Annals. 51, 116-128. https://doi.org/10.1111/flan.12316

Whyte, S., \& Schmid, E. C. (2019). Classroom technology for young learners. In S. Garton \& F. Copland (Eds.). The Routledge Handbook of Teaching English to Young Learners (pp. 338-355). London: Routledge.

Wichadee, S., \& Pattanapichet, F. (2018). Enhancement of Performance and Motivation Through Application of Digital Games in an English Language Class. Teaching English with Technology, 18(1), 77-92.

Williams, A. (2017). History of Digital Games: Development in art, design and interaction. Boca Raton. FL: Focal Press.

Yunus, M. M. (2018). Innovation in Education and Language Learning in 21st Century. Journal of Sustainable Development Education and Research, 2(1), 33-34.

Zhang, Z., Nagle, J., McKishnie, B., Lin, Z., \& Li, W. (2019). Scientific strengths and reported effectiveness: a systematic review of multiliteracies studies, Pedagogies: An International Journal, 33-61. https://doi.org/10.1080/1554480X.2018.1537188 